\title{
Pembuatan Sabun Aroma Teraphi untuk Masyarakat Pedesaan
}

\author{
$1^{1 *}$ Aman Santoso, ${ }^{2}$ Ida Bagus Suryadarma, ${ }^{3}$ Sumari, ${ }^{4}$ Dedek Sukarianingsih \\ Universitas Negeri Malang; Jalan Semarang 5 Malang \\ *Corresponding author: aman.santoso.fmipa@um.ac.id
}

\begin{abstract}
Abstrak
Kelompok tani wilayah ponggok berpotensi sebagai penghasil produk agro seperti buah-buahan dan juga minyak atsiri seperti bunga kenanga, nilam, sereh dan cengkeh. Minyak atsiri dapat diisolasi dengan cara destilasi air, dan destilasi air-uap. Masyarakat banyak menghasilkan limbah minyak goreng. Limbah minya tidak baik untuk kesehatan dn juga mencemari lingkungan. Hasil potensi desa bisa dimanfaatkan sebagai unggulan masyarakat desa. Dengan reaksi saponifikasi minyak dapat diubah menjadi sabun. Hasil kegiatan ini menunjukkan bahwa masyarakat sangat antusias dan bisa membuat sabun cair dengan bahan baku minyak goreng, dikatalis basa, sedikit texafone, serta gloserin serta sedikti aroma minyak aisiri.
\end{abstract}

Kata kunci-minyak atsiri, sabun, minyak sawit, masyarakat desa.

\section{Abstract}

Ponggok area farmers groups have the potential to produce agro products such as fruits and essential oils such as cananga, patchouli, lemongrass and clove. Essential oils can be isolated by water distillation, and watersteam distillation. Many people produce cooking oil waste. Oil waste is not good for health and also pollutes the environment. Village results can be used as a superior village community. With the saponification reaction the oil can be turned into soap. The findings of these activity showed that the community is very enthusiastic and can make liquid soap with raw materials for cooking oil, alkaline catalysts, a little texafone, as well as gloserin and a little aroma of essential oils.

Keywords—essential oil, soap, palm oil, rural communities

\section{PENDAHULUAN}

$\mathrm{M}$

inyak atsiri adalah minyak dengan sifat mudah menguap yang berasal tumbuh-tumbuhan, sifat fisiknya pada suhu kamar berwujud cair dan mudah menguap. Banyak tumbuhan memberikan aroma yang khas, dan minyak ini juga disebut sebagai minyak eterik (aetheric oil), minyak esensial (essential oil), minyak terbang (volatile oil), serta minyak aromatik (aromatic oil). Minyak atsiri merupakan bahan dasar dari wangi-wangian atau minyak gosok (untuk pengobatan) alami. Minyak atsiri juga disebut essential oil (minyak essen) karena bersifat khas sebagai pemberi aroma/bau (esen) (Pratiwi \& Utami, 2018). Setiap tumbuhan memiliki sifat atau komponen yang spesifik, misalnya minyak kenanga, minyak mawar, minyak nilam dan lain sebagainya. Minyak Atsiri memiliki sifat dapat didestilasi, tidak meninggalkan noda, tidak tersabunkan, tidak tengik, tidak mengandung asam. Sifat minyak ini sangat berbeda dengan sifat minyak nabati yang termasuk trigliserida seperti minyak kelapa, minyak, sawit, minyak kacang dan lain sebagainya.

Minyak atsiri dapat bersumber pada setiap bagian tanaman yaitu dari daun, bunga, buah, biji, batang atau kulit dan akar atau rhizome (Tanasale, 2012). Berbagai macam tanaman yang dibudidayakan atau tumbuh dengan sendirinya di berbagai daerah di Indonesia memiliki potensi yang besar untuk diolah menjadi minyak atsiri, baik yang unggulan maupun potensial untuk dikembangkan. Khususnya di Indonesia telah dikenal sekitar 40 jenis tanaman penghasil minyak atsiri, namun baru sebagian dari jenis tersebut telah digunakan sebagai sumber minyak atsiri secara komersil (Tirta \& Wibawa, 2017)

Berikut adalah daftar tanaman atsiri penghasil minyak atsiri yang tumbuh di Indonesia, bagian tanaman contoh yang bersumber dari akar: Akar Wangi, Kemuning. Daun: Nilam, Cengkeh, Sereh Lemon, Sereh Wangi, Sirih, Mentha, Kayu Putih, Gandapura, Jeruk Purut, Karmiem, Krangean, Kemuning, Kenikir, Kunyit, Selasih, Kemangi. Biji: Pala, Lada, Seledri, Alpukat, Kapulaga, Klausena, 
Kasturi, Kosambi. Buah: Adas, Jeruk, Jintan, Kemukus, Anis, Ketumbar. Bunga: Cengkeh, Kenanga, Ylang-Ylang, Melati, Sedap Malam, Cempaka Kuning, Daun Seribu, Gandasuli Kuning, Srikanta, Angsana, Srigading. Kulit Kayu: Kayu Manis, Akasia, Lawang, Cendana, Masoi, Selasihan, Sintok. Ranting: Cemara Gimbul, Cemara Kipas. Rimpang: Jahe, Kunyit, Bangel, Baboan, Jeringau, Kencur, Lengkuas, Lempuyang Sari, Temu Hitam, Temulawak, Temu Putri. Seluruh bagian: Akar Kucing, Bandaton, Inggu, Salasih, Sudamala, Trawas.

Minyak atsiri digunakan sebagai bahan dasar kosmetik, parfum, aroma terapi, obat, suplemen dan makanan (Arimurti, 2017). Penggunaan minyak atsiri sebagai obat dan suplemen semakin diminati masyarakat seiring berkembangnya produk-produk herbal. Minyak Atsiri banyak digunakan bisa sebagai minyak tunggal atau sebagai minyak campuran dari beberapa sumber, sebagai minyak murni seperti pada Gambar 1.

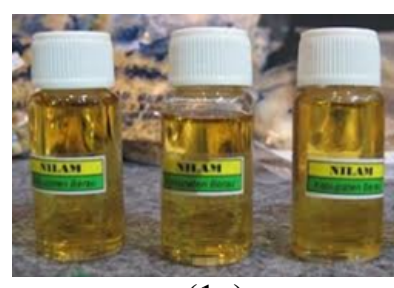

(1a)

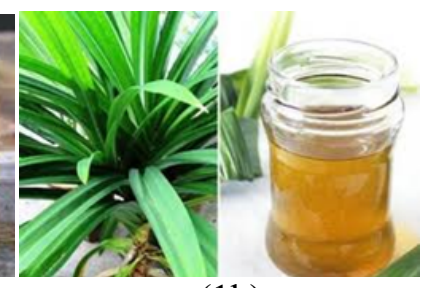

(1b)
Gambar (1a) Minyak nilam (1b) Minyak panda

Sabun merupakan surfaktan yang memiliki tegangan permukaan rendah, dibuat dengan mereaksikan minyak nabati atau hewani dengan kalium atau natrium hidroksida. Sabun mengandung agen pengemulsi yang biasanya digunakan untuk pembersih. Sabun mengandung ion positif, biasanya $\mathrm{Na}^{+}$atau $\mathrm{K}^{+}$, dan ion negatif. Biasanya anion ini berasal dari asam karboksilat rantai panjang yang diperoleh dari hidrolisis minyak nabati atau hewani (Narkhede, 2010).

Sabun memiliki struktur kimiawi dengan panjang rantai karbon $\mathrm{C} 12$ hingga $\mathrm{C} 16$. Sabun bersifat ampifilik, yaitu pada bagian kepalanya memiliki gugus hidrofilik (polar), sedangkan pada bagian ekornya memiliki gugus hidrofobik (non polar), oleh sebab itu, dalam fungsinya, gugus hidrofobik akan mengikat molekul lemak dan kotoran, yang kemudian akan ditarik oleh gugus hidrofilik yang dapat larut di dalam air (Nurhadi, 2012). Fajri (2012) menyatakan bahwa sabun memiliki kelarutan yang tinggi dalam air, tetapi sabun tidak larut menjadi partikel yang lebih kecil, akan tetapi larut dalam bentuk ion.
Sabun mempunyai beberapa bentuk yang sering dijumpai di pasaran, yaitu bentuk padat (batang), serbuk (detergen), gel, dan cair. Narkhede (2010) menyatakan bahwa sabun dapat dibuat sesuai tipe kulit dan aroma yang diinginkan. Nurhadi (2012), menyatakan bahwa masing-masing jenis sabun tersebut memiliki keunggulan tersendiri, seperti aroma, bentuk, dan fungsi, yaitu baik pelembut kulit, ataupun sebagai anti bakteri.

Sabun juga dapat bertindak sebagai agen pembersih dan antibakteri. Desiyanto dan Djannah (2013) menyatakan bahwa sabun dapat lebih efektif menghilangkan kotoran dan debu secara mekanis dari permukaan kulit dan secara bermakna mengurangi jumlah mikroorganisme penyebab penyakit seperti virus, bakteri dan parasit lainnya. Nurhadi (2012) menyatakan bahwa sabun dipercaya dapat membersihkan kulit secara efektif, didukung oleh sifat antibakteri yang dimilikinya.

\section{METODE}

\section{a. Teknik Isolasi Minyak Atsiri}

Minyak atsiri pernah menjadi primadona ekspor Indonesia. Sebagai misalnya daerah Jawa barat banyak menghasilkan akar wangi, daerah Jawa Timur khususnya di Blitar Minyak Kenanga, Minyak cengkeh di Malang, Tulungagung dan Trenggalek. Teknik isolasi minyak atsiri dapat dilakukan dengan beberapa cara yaitu: 1) penyulingan (distillation), 2) pengepresan (pressing), 3) ekstraksi dengan pelarut menguap (solvent extraction), 4) ekstraksi dengan lemak.

\section{b. Penyulingan Minyak Atsiri.}

Minyak atisiri atau minyak terbang mempunyai sifat minyak yang mudah menguap, seifatnya dapat larut dalam air panas dan tidak larut dalam air dingin. Oleh karena itu teknik isolasinya biasanya dilakukan dengan cara destilasi. Minyak atsiri adalah disebut juga minyak terbang. Kandungan minyak dalam tumbuhan tergantung pada jenis, dan bagian dari tumbuhan. Minyak atsiri banyak tertdapat dalam akar, batang, daun dan bunga. Proses isolasi minyak atsiri bisa dilakukan dengan cara ekstraksi, destilasi air, dan destilasi uap.

\section{c. Penyulingan Dengan Air dan Uap}

Pada model penyulingan ini, bahan tanaman yang akan disuling diletakkan di atas rak-rak atau saringan berlubang. Kemudian ketel penyulingan diisi dengan air sampai permukaannya tidak jauh dari bagian bawah saringan. Ciri khas model ini yaitu uap selalu dalam keadaan basah, jenuh, dan tidak terlalu panas. Bahan tanaman yang akan disuling hanya 
berhubungan dengan uap dan tidak dengan air panas (Lutony \& Rahmayati, 1994).

\section{d. Metode Pengepresan}

Ekstraksi minyak atsiri dengan cara pengepresan umumnya dilakukan terhadap bahan berupa biji, buah, atau kulit buah yang memiliki kandungan minyak atsiri yang cukup tinggi. Akibat tekanan pengepresan, maka sel-sel yang mengandung minyak atsiri akan pecah dan minyak atsiri akan mengalir ke permukaan bahan. Contohnya minyak atsiri dari kulit jeruk dapat diperoleh dengan cara ini (Ketaren, 1985).

Minyak atsiri dapat diperoleh dari berbagai tanaman di Indonesia. pemanfaatan atsiri untuk bisnis juga sangat menguntungkan karena harga jual minyak atsiri di pasaran tidak bisa dianggap remeh. Manfaat minyak atsiri dapat digunakan sebgai bahan baku parfum, sabun, detergen, kosmetikan dan juga untuk keperluan farmasi.

\section{e. Pembuatan Sabun Aroma Terapi}

Berdasarkan bentuknya sabun dibedakan menjadi dua, yakni padat dan sabun cair. Sabun dibuat dengan mereaksikan minyak nabati dengan basa $(\mathrm{NaOH}$ atau $\mathrm{KOH})$. Sabun yang dibuat dengan menggunakan basa sodium $(\mathrm{NaOH})$ disebut sabut keras dan sabun yang dibuat dengan menggunakan basa kalium $(\mathrm{KOH})$ disebut sabun lunak.

Pembuatan dapat dilakukan dengan di awali dengan mempersiapkan alat bahan yang diperlukan. Peralatan yang diperlukan dalam pembuatan sabun yakni: seperangkat beaker glass $50 \mathrm{~mL}$, erlenmeyer $50 \mathrm{~mL}$, buret $50 \mathrm{~mL}$, kaca pengaduk, gelas arloji, spatula, mortar dan pestle, timbangan ohaus dengan ketelitian $0,1 \mathrm{~g}$, neraca digital merk Shimadzu dengan ketelitian 0,0001 g, termometer, pemanas mantel, hotplate stirer, jarum ose, gelas ukur $5 \mathrm{~mL}$, gelas ukur $100 \mathrm{~mL}$, labu takar $25 \mathrm{~mL}$, labu takar 100 $\mathrm{mL}$, pipet. Bahan-bahan yang digunakan adalah minyak kemiri, $\mathrm{KOH}$ (p.a), sodium lauryl sulfate, gliserin, butyl hidroksi toluene (BHT), aquades, asam sitrat, phenolftalein, etanol $96 \%$, bacto pepton, nutrient agar, $\mathrm{KOH} 0,5 \mathrm{M}, \mathrm{HCl} 0,5 \mathrm{M}$, bakteri Escherichia coli dan Staphylococcus aureus.

Tahapan umum pembuatan sabun dari minyak adalah sebagai berikut; Minyak nabati dipanaskan pada temperatur $\pm 70^{\circ} \mathrm{C}$, kemudian ditambah dengan larutan $\mathrm{KOH}$. Setiap selang waktu 15 menit ditambahkan bahan-bahan tambahan lain seperti gliserin untuk melembabkan kulit, surfaktan sodium lauryl sulfate sebagai pengemulsi, butil hidroksi toluena (BHT) sebagai antioksidan, dan asam sitrat untuk mengatur $\mathrm{pH}$ sabun. Sebagai penciri khas dari produk lokal masyarakat, sabun yang dibuat ditambahkan minyak atsiri hasil daerah setempat yaitu, minyak kenanga dan nilam.

\section{HASIL DAN PEMBAHASAN}

\section{a. Isolasi Minyak Atsiri}

Pada skala idustri isolasi minyak atisiri banyak digunakan cara destilasi air dan destilasi uap air, karena prosesnya lebih serhana dan murah. Peralatan yang digunakan untuk isolasi minyak atsiri dengan destilasi air pada skala laboratorium dan industri rumah tangga adalah seperti pada Gambar 1.
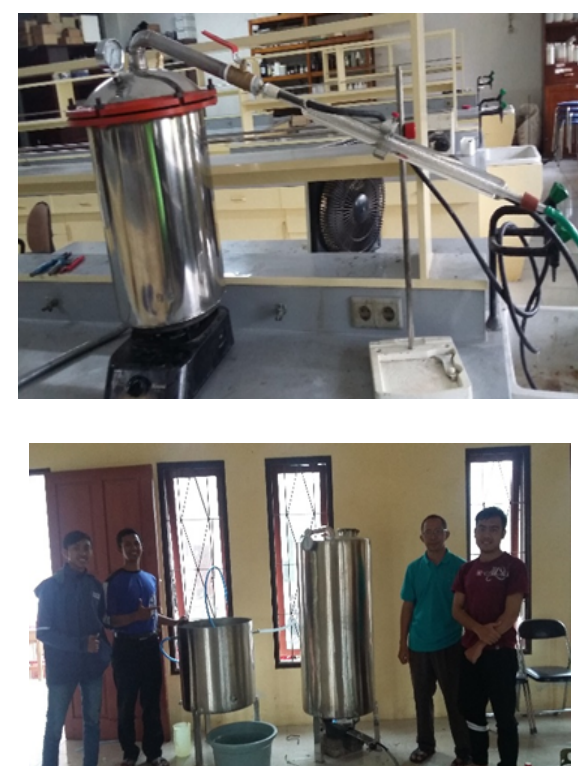

Gambar 2. Ketel isolasi minyak atsiri skala Lab dan Skala industri

Bahan yang disolasi adalah semua bahan tumbuhan yang memiliki bau yang khas dan mudah menguap, dengan sifat larut pada uap air panas dan tidak larut atau sedikit larut pada air dingin. Bahan yang mengandung minyak atsiri misalnya bungan kenanga, mawar, daun cengkeh, nilam dan kayu putih, dengan contoh seperti pada Gambar 2.

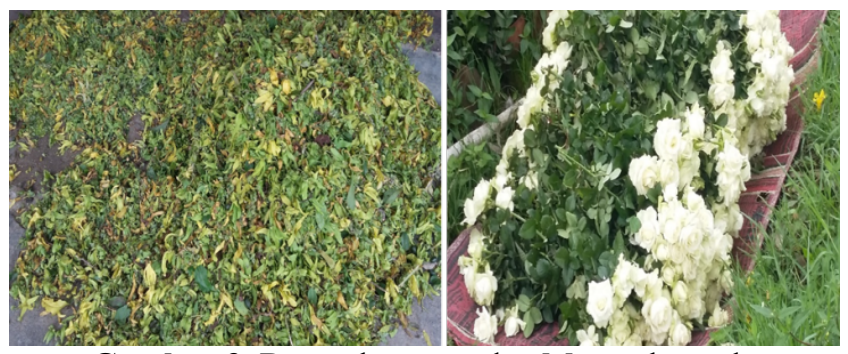

Gambar 3. Bunga kenanga dan Mawar banyak mengandung minyak atsiri 
Hasil destilasi minyak atsiri, berupa destilat yang membentuk dua lapisan. Dimana lapisan atas berupa minyak dan bagian bawah berupa air seperti pada Gambar 3.

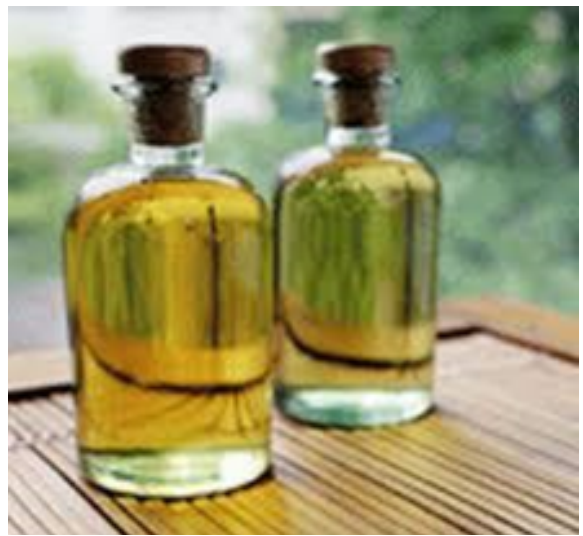

Gambar 4. Minyak kenanga hasil destilasi

Hasil destilasi merupakan campuran air dan atsiri, sehingga apabila ingin diperoleh atsiri yang murni harus dilakukan pemisahan. Caranya adalah larutan tersebut dimasukkan kedalam corong pisah dan dikocok-kocok sehingga akan diperoleh 2 lapisan. Lapisan atas merupakan minyak atsiri dan lapisan bawah merupakan air. Hal itu dikarenakan massa jenis minyak lebih kecil daripada masa jenis air. Minyak atsiri merupakan produk andalan petani untuk beberapa daerah, seperti minyak kenanga banyak dihasilkan di daerah Blitar dan Pasuruan, minyak cengkeh banyak dihasilkan di Blitar, Trenggalek dan Malang Jawa Timur.

\section{b. Praktek Pembuatan Sabun}

Reaksi penyabunan atau yang biasa disebut dengan reaksi saponifikasi adalah reaksi yang umumnya digunakan untuk mensintesis sabun. Persamaan reaksinya sebagai berikut:

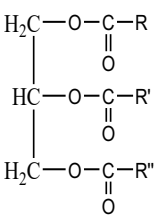

triasilgliserol Kalium hidroksida

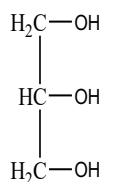

gliserol

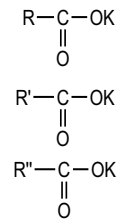

garam Kalium dari Asam Lemak (Sabun Kalium)
Reaksi tersebut menunjukkan 1 mol trigliserida direaksikan dengan $3 \mathrm{~mol} \mathrm{KOH}$ untuk membentuk campuran kalium karboksilat dan gliserol. Persamaan reaksi tersebut menunjukkan bahwa sabun yang terbentuk adalah sebuah garam yang tersusun dari campuran karboksilat sebagai anionnya dan kalium sebagai kationnya. Atiku dkk. (2014) mengatakan bahwa terbentuknya anion campuran tersebut karena molekul trigiserida memiliki residu asam lemak yang bermacammacam, yang berasal dari lemak atau minyak trigliserida itu sendiri.

Didaerah pedesaan banyak dihasilkan limbah minyak goreng, yang sebenarnya berpotensi untuk dijadikan sabun. Masyarakat pedesaan tidak punya ketrampilan melakukan hal tersebut, sehingga perlu pendampingan dari perguruan tinggi. Persipanan alat dan bahan untuk praktek pembuatan sabun seperti pada Gambar 4 sangat diperlukan agar pelatihan dimasyarakat berhasil dengan baik.
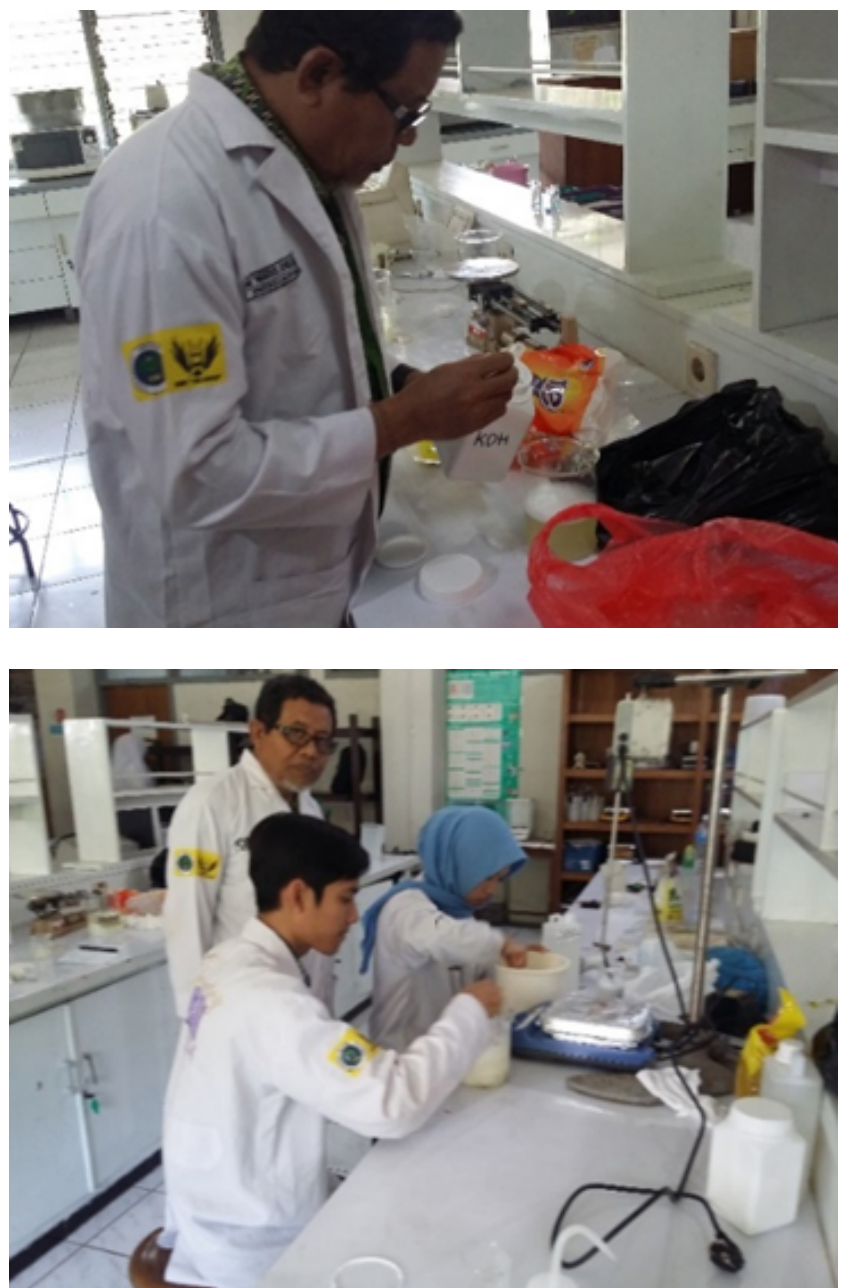

Gambar 5. Preparasi Pembuatan sabun

Hasil akhir sabun berupa sabun padatan dengan sifat padat lunak, bau nilam berpadu dengan bunga kenanga, mawar. Karena bahan bakunya dari kombinasi minyak atsiri tersebut. Ketrampilan pembuatan sabun ini dapat diimplementasikan ke masyarakat pedesaan, yang selama ini banyak waktu luang, dan banyak limbah minyak oreng, yang berpotensi bisa sebagai bahan baku sabun. Masyarakat bisa dilatihkan praktek pembuatan sabun 
beroma terapi. Seperti pada Gambar 6, Ibu-ibu PKK mendemokan cara membuat sabun.
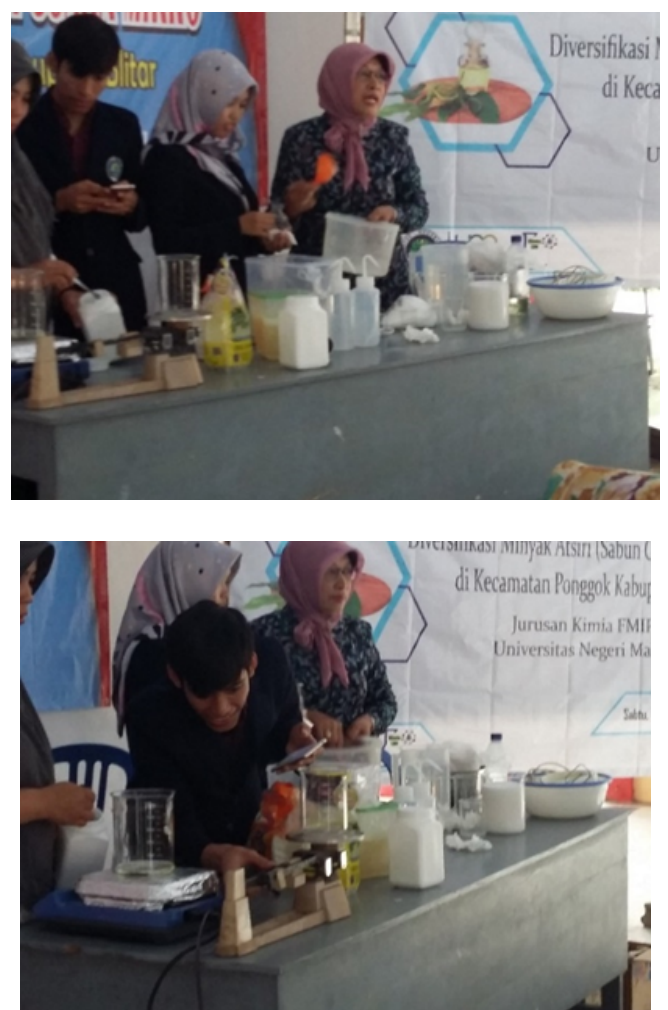

Gambar 6. Praktek masyarakat dalam pebuatan sabun

Praktek pembuatan di masyarakat sangat memberikan kesan positif pada masyarakat. Hela tersebut karena memberikan bekal ketrampilan bagi masyrakat, dan meminimalisasi limbah minyak goring.

\section{SIMPULAN}

Minyak atsiri dapat diisolasi dengan cara destilasi air, dan destilasi air-uap, dan Kelompok tani wilayah Ponggo berpotensi sebagai penghasil minyak atsiri khususnya bunga kenanga, sereh, nilam. Masyarakat sangat antusias dan bisa membuat sabun cair dengan bahan baku minyak goreng, basa, sedikit texafone, serta gloserin serta sedikit aroma minyak atisiri.

\section{DAFTAR RUJUKAN}

Atiku, F. A., Fakai, I. M., Wara, A. A., Birnin-Yauri, A. U., Musa, M. A. (2014). Production of Soap Using Locally Available Alkaline Extract from Millet Stalk: A Study on Physical and Chemical Properties of Soap. IJARCS, 1(7), 1-7.

Arimurti, A. R. R. (2017). Efektivitas minyak atsiri serai wangi (combypogon nardus) sebagai insektisida alami untuk kecoa amerika (periplaneta americana). The Journal of Muhammadiyah Medical Laboratory Technologist, 1(1), 55-60.

Desiyanto, F. A., \& Djannah, S. N. (2013). Efektifitas Mencuci Tangan Menggunakan Cairan Pembersih Tangan Antiseptik (Hand Santizer) Terhadap Jumlah Angka Kuman. Kesmas, 7(2), 55-112.

Fajri, A. S. (2012). Perbedaan Pengaruh Antara Pemberian Aromaterapi Lavender dan Sabun Cair Ekstrak Minyak Kelapa Menggunakan Metode Inhalasi Terhadap Kelelahan Otot Akibat Penumpukan Asam Laktat Darah. Skripsi tidak diterbitkan. Malang: Fakultas Ilmu Keolahragaan Universitas Negeri Malang.

Ketaren, S. (1986). Pengantar Teknologi Minyak dan Lemak Pangan. 261-263 Cetakan pertama, Penerbit Universitas Indonesia: Jakarta.

Narkhede, D. B. (2010). Formulation and Evaluation of Coconut Oil Liquid Soap. IJPWR, 1(2), 1-15.

Nurhadi, S. C. (2012). Pembuatan Sabun Mandi Gel Alami dengan Bahan Aktif Mikroalga Chlorella pyrenoidosa Beyerinck dan Minyak Atsiri Lavandula latifolia Chaix. Laporan tidak diterbitkan. Malang: Fakultas Sains dan Teknologi Universitas Ma Chung.

Pratiwi, A., \& Utami, L. B. (2018). Isolasi dan Analisis Kandungan Minyak Atsiri pada Kembang Leson. Bioeksperimen: Jurnal Penelitian Biologi, 4(1), 42-47.

Tanasale, M. L. P. (2012). Aplikasi Perlakuan Bahan Baku dan Penyulingan Air-Uap Terhadap Rendemen dan Sifat Organoleptik Minyak Astiri. Ekosains, 1(1), 35-40.

Tirta, I., \& Wibawa, I. P. A. H. (2017). Eksplorasi Tumbuhan Yang Berpotensi Sebagai Penghasil Minyak Atsiri Di Lombok Timur-NTB. Jurnal Biologi Udayana, 21(1), 12-16. 